\title{
Quantitative trait loci mapping of calving and conformation traits on Bos taurus autosome 18 in the German Holstein population
}

\author{
B. Brand, ${ }^{*}$ C. Baes, $† \ddagger$ M. Mayer, $†$ N. Reinsch, $†$ T. Seidenspinner, $\S$ G. Thaller,§ and Ch. Kühn*1 \\ ${ }^{*}$ Research Unit Molecular Biology and \\ †Research Unit Genetics and Biometry, Research Institute for the Biology of Farm Animals (FBN), D-18196 Dummerstorf, Germany \\ $\ddagger$ Department of Animal Husbandry and Animal Breeding, University Hohenheim, D-70593 Stuttgart, Germany \\ §Institute for Animal Breeding and Husbandry, Christian-Albrechts-University, D-24098 Kiel, Germany
}

\begin{abstract}
Linkage, linkage disequilibrium, and combined linkage and linkage disequilibrium analyses were performed to map quantitative trait loci (QTL) affecting calving and conformation traits on Bos taurus autosome 18 (BTA18) in the German Holstein population. Six paternal half-sib families consisting of a total of 1,054 animals were genotyped on 28 genetic markers in the telomeric region on BTA18 spanning approximately 30 $\mathrm{Mb}$. Calving traits, body type traits, and udder type traits were investigated. Using univariately estimated breeding values, maternal and direct effects on calving ease and stillbirth were analyzed separately for firstand further-parity calvings. The QTL initially identified by separate linkage and linkage disequilibrium analyses could be confirmed by a combined linkage and linkage disequilibrium analysis for udder composite index, udder depth, fore udder attachment, front teat placement, body depth, rump angle, and direct effects on calving ease and stillbirth. Concurrence of QTL peaks and a similar shape of restricted log-likelihood ratio profiles were observed between udder type traits and for body depth and calving traits, respectively. Association analyses were performed for markers flanking the most likely QTL positions by applying a mixed model including a fixed allele effect of the maternally inherited allele and a random polygenic effect. Results indicated that microsatellite marker DIK4234 (located at $53.3 \mathrm{Mb}$ ) is associated with maternal effects on stillbirth, direct effects on calving ease, and body depth. A comparison of effects for maternally inherited DIK4234 alleles indicated a favorable, positive correlation of maternal and direct effects on calving. Additionally, the association of maternally inherited DIK4234 marker alleles with body depth implied that conformation traits might provide the functional background of the QTL for calving traits. For udder type traits, the strong coincidence
\end{abstract}

Received July 8, 2009.

Accepted October 9, 2009.

${ }^{1}$ Corresponding author: kuehn@fbn-dummerstorf.de of QTL peaks and the position of the QTL in a region previously reported to harbor QTL for somatic cell score indicated that effects of QTL for udder type traits might be correlated with effects of QTL for udder health traits on BTA18. Our results suggest that loci in the middle to telomeric region on BTA18 with effect on conformation traits may also contribute to the genetic variance of calving and udder health traits. Further analyses are required to identify the causal mutations affecting conformation and calving traits and to investigate the correlation of effects for loci associated with conformation, calving, and udder health traits.

Key words: conformation trait, calving ease, stillbirth, Bos taurus autosome 18

\section{INTRODUCTION}

Economically important traits are considered to be traits favorably affecting economic efficiency by increasing the productive output of an animal or decreasing the treatment and replacement costs (Groen et al., 1997). Many studies on dairy cattle in the past 2 decades have focused on identification of chromosomal regions and genes affecting production traits to improve productivity by implementing the genetic information gained in upcoming breeding strategies (Kalm, 2002; Oltenacu and Algers, 2005). The focus has recently changed because strong selection on milk production traits has unfavorably affected functional traits like fertility, health, and longevity (Essl, 1998; Oltenacu and Algers, 2005), and many studies reported unfavorable correlations between milk production traits and functional traits (Simianer et al., 1991; Holtsmark et al., 2008). Hence, traits affecting health, fertility, and calving performance have become increasingly important for the economic efficiency of dairy cattle because they have a strong effect on replacement costs and costs for veterinary treatments (Groen et al., 1997; Kalm, 2002). However, selection on functional traits is hampered by 3 aspects: the low heritability of functional traits, the difficulties in defining and recording these traits (Mark, 2004; Mark et al., 2007), and the unfavorable genetic 
correlation to production traits. In German Holstein cattle, Kühn et al. (2003) reported putative QTL for functional herd life, dystocia, stillbirth, nonreturn rate at $90 \mathrm{~d}$, and SCC on BTA18, indicating that genetic variants on BTA18 could have a strong influence on traits affecting economic efficiency in the German Holstein population. Recent studies confirmed QTL for calving traits (Kolbehdari et al., 2008; Thomasen et al., 2008) and SCS (Xu et al., 2006; Lund et al., 2007; Baes et al., 2009) on BTA18, and several studies reported QTL for conformation traits that are segregating on the same chromosome (Ashwell et al., 2005; Schnabel et al., 2005; Kolbehdari et al., 2008). Recently, Cole et al. (2009) investigated calving traits and conformation traits in North American Holstein bulls. They identified an SNP on BTA18 that has large effects on calving ease and body type traits and proposed that these effects are attributed to a single gene locus that is associated with calf birth weight or calf size.

One aim of this study of the German Holstein population was the confirmation of QTL for calving traits initially reported by Kühn et al. (2003). Furthermore, we wanted to test whether there are QTL for conformation traits on BTA18 that might indicate the functional background of QTL for calving performance and udder health on this chromosome.

\section{MATERIALS AND METHODS}

\section{Animals}

The animals available for genotyping comprised a granddaughter design described previously by Baes et al. (2009), which consisted of 6 paternal German Holstein half-sib families with a total of 1,054 animals. Numbers of sons per family ranged from 60 to 353 per grandsire, with an average size of 175 sons per family. Additional pedigree information comprising nongenotyped ancestors of genotyped animals (7,627 animals) was provided by the German genetic evaluation center (VIT) in Verden, Germany, for estimating random polygenic effects.

\section{Phenotypes}

Phenotypic information for genotyped animals was provided by the VIT. Three groups of traits were analyzed in this study: udder type traits, body type traits, and calving traits. Udder type traits considered were the udder composite index, udder support, udder depth, fore udder attachment, rear udder height, front teat placement, rear teat placement, and teat length. Body type traits analyzed were stature, body depth, chest width, rump angle, and rump width. The definitions of conformation traits for cattle are available at the VIT web site (http://www.vit.de/index. php?id=milchrinder-zws-online $\& \mathrm{~L}=1$ ).

Phenotypic information for conformation traits was provided as daughter yield deviations (DYD) from the national genetic evaluation process, and reliabilities associated with DYD were expressed as the number of effective daughter contribution (EDC). The DYD and EDC were obtained from the official data release of the January 2008 genetic evaluation.

Phenotypic data for calving traits were individual calving records, defined as maternal and direct effects on stillbirth and calving ease. Maternal (m) effects on calving traits were further separated in first-, second-, and third-parity calvings $(\mathrm{m} 1, \mathrm{~m} 2$, and $\mathrm{m} 3$, respectively), and direct effects on calving traits were separated in first- and further-parity (p) calvings (p1 and p2, respectively). Sire breeding values for these traits were estimated based on the following model:

$$
\begin{aligned}
y_{i j k l m n}= & \mu+H \times Y_{j}+C M_{k}+C S_{l} \\
& +A C_{m}+s_{n}+e_{i j k l m n},
\end{aligned}
$$

where $y_{i j k l m n}$ is the calving observation for offspring $i$ of sire $n$ (direct effects) or daughter $i$ of sire $n$ (maternal effects); $\mu$ is the overall mean; $H \times Y_{j}$ is the fixed effect of $j$ th herd by year of calving interaction; $C M_{k}$ is the fixed effect of $k$ th calving month; $C S_{l}$ is the fixed effect of $l$ th sex of the calf class; $A C_{m}$ is the fixed effect of the cow's calving age; $s_{n}$ is the random sire effect; and $e_{i j k l m n}$ is the random residual effect.

Each calving trait was analyzed separately. We selected univariately estimated breeding values for our QTL analyses because any mixture of phenotypes (e.g., a mixture of direct and maternal effects) that have a divergent physiological background (e.g., size or vitality of the calf vs. size and proportion of the dam's pelvis) would be detrimental for revealing QTL of a specific trait (Seidenspinner et al., 2009). The preference of univariately estimated breeding values for QTL analyses is further advocated by the observation that genetic correlations between traits calculated at the level of the entire genome (when all genetic loci affecting a trait are considered) are not necessarily identical to correlations at single loci, which is exemplified by the negative correlation of the effects of the DGAT1 K232A locus on milk fat and milk protein yield (Thaller et al., 2003).

Especially for traits with low heritability and a strong difference between sires in the number of daughter records, a situation typically observed for calving traits, information coming from half-sibs can substantially 
Table 1. Summary and description of traits and mean, standard deviation, minimum, maximum, and median for daughter yield deviations or deregressed breeding values

\begin{tabular}{|c|c|c|c|c|c|c|c|}
\hline Trait $^{1}$ & Number of sons & Heritability & Mean & $\mathrm{SD}$ & Minimum & Maximum & Median \\
\hline Udder support & 1,039 & 0.13 & 137.07 & 284.039 & -786 & 1,061 & 147 \\
\hline Udder depth & 1,039 & 0.26 & 96.679 & 333.502 & $-1,121$ & 1,241 & 114 \\
\hline Rear udder height & 1,039 & 0.22 & 98.498 & 292.067 & -954 & 1,001 & 91 \\
\hline Front teat placement & 1,039 & 0.22 & 46.005 & 347.596 & $-1,210$ & 1,027 & 50 \\
\hline Rear teat placement & 325 & 0.28 & 156.262 & 506.5 & $-2,484$ & 3,380 & 164 \\
\hline Body depth & 1,039 & 0.24 & 8.017 & 334.737 & $-1,282$ & 1,124 & 9 \\
\hline Chest width & 1,036 & 0.18 & -70.261 & 298.311 & $-1,067$ & 1,064 & -62.5 \\
\hline Rump angle & 1,039 & 0.26 & 29.268 & 353.411 & $-1,000$ & 1,205 & 22 \\
\hline Rump width & 1,039 & 0.28 & -37.245 & 360.101 & $-1,235$ & 1,112 & -49 \\
\hline Calving ease m1 & 890 & 0.05 & -0.0001 & 0.039 & -0.151 & 0.152 & -0.002 \\
\hline Calving ease m2 & 906 & 0.05 & 0.0004 & 0.029 & -0.117 & 0.123 & -0.003 \\
\hline Calving ease $\mathrm{m} 3$ & 909 & 0.05 & 0.001 & 0.023 & -0.089 & 0.101 & -0.002 \\
\hline Stillbirth p1 & 356 & 0.05 & 0.003 & 0.027 & -0.062 & 0.119 & 0.001 \\
\hline Stillbirth p2 & 924 & 0.05 & 0.0007 & 0.012 & -0.033 & 0.064 & 0 \\
\hline
\end{tabular}

${ }^{1} \mathrm{~m} 1$ = maternal effects, first-parity calvings; $\mathrm{m} 2=$ maternal effects, second-parity calvings; $\mathrm{m} 3=$ maternal effects, third-parity calvings; 1 = direct effects, first-parity calvings; $22=$ direct effects, second- and further-parity calvings.

reduce the power of QTL mapping (Seidenspinner et al., 2009). Thus, we did not include further pedigree information to avoid decreased QTL mapping power caused by regression of EBV within half-sib families toward single superior sires with high reliabilities of EBV. The EBV and DYD were provided in the original scale, with negative values being favorable and positive values being unfavorable. Minimum contemporary herd by calving year group was set to 5 and the minimum number of total observations per sire was 30 to be included in the analysis.

To obtain DYD for calving traits, sire EBV were deregressed by dividing each estimated breeding value by twice its reliability squared. For QTL analyses, DYD were weighted corresponding to Kühn et al. (2003) as follows:

$$
\omega^{-1}=\left\{\left[1+0.25 h^{2}(n-1)\right] / n\right\} \sigma_{p}^{2},
$$

where $\omega$ is the variance of the half-sib mean; $h^{2}$ is the heritability of the trait; $\sigma_{p}^{2}$ is the phenotypic variance; and $n$ was set equal to the number of EDC for conformation traits, the number of calves for direct calving traits by parity, and the number of daughters for maternal calving traits by parity. A summary of traits, number of available phenotypes, and the heritability of each trait used for weighting is given in Table 1.

\section{Marker Set and Linkage Map}

The marker set included a total of 28 markers: 7 SNP, 20 microsatellite markers, and the erythrocyte antigen marker EAC (Table 2). The markers cover 50 $\mathrm{cM}$ corresponding to $30 \mathrm{Mb}$ of the middle to telomeric region on BTA18 ranging from $C D H 1$ (cadherin 1, type 1) to DIK4013. Microsatellite markers were genotyped by automated fragment analysis using the MegaBace 1000 DNA Analysis System and MegaBace Fragment Profiler software (version 1.2, GE Healthcare, Munich, Germany). The SNP were genotyped by RFLP analyses or pyrosequencing using the PSQHS 96A pyrosequencing system (Biotage AB, Uppsala, Sweden). The EAC genotypes were determined by routine blood typing laboratories according to standard procedures (Schmid and Buschmann, 1985; Thomsen et al., 2002). All genotypes were checked for Mendelian inheritance and unlikely double recombinants. The genetic linkage map was calculated based on a refined marker order using CRIMAP software (Green et al., 1990). In some marker groups no recombination was observed. To avoid technical difficulties arising when calculating transmitting probabilities, the marker spacing was set to small values greater than zero. The polymorphism information content for each marker was calculated using PowerMarker software (version 3.25; Liu and Muse, 2005).

\section{Mapping Procedure}

The QTL analyses were conducted as described in Baes et al. (2009). The linkage (LK) and linkage disequilibrium (LD) analyses were performed for each trait by calculating a restricted log-likelihood ratio 
Table 2. Characteristics of markers in the middle to telomeric region of BTA18

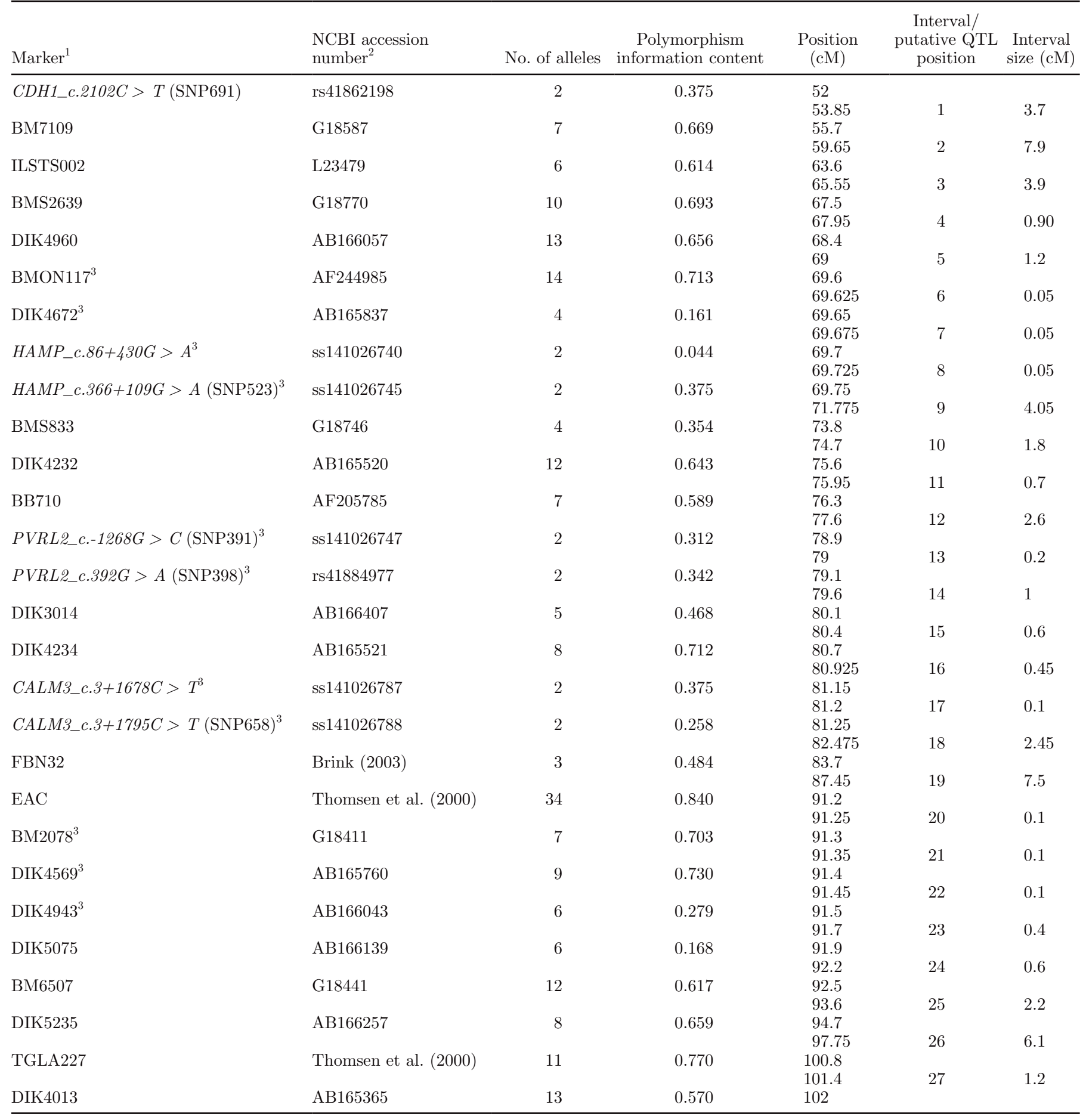

${ }^{1}$ Marker names in brackets are as per Baes et al. (2009).

${ }^{2} \mathrm{NCBI}=$ National Center for Biotechnology Information. For markers without an accession number, a literature reference is provided.

${ }^{3}$ Marker of intervals with marker spacing set to small values greater than zero.

test statistic (RLRT) for each putative QTL position. Combined LKLD analyses were performed only for traits that showed at least chromosome-wide significance in LK or that were close to chromosome-wide significance (RLRT $>7$ ) in LD. Significance thresholds were calculated using the restricted RLRT equivalents of 9.2 for chromosome-wide and 13.8 for genome-wide significance corresponding to Baes et al. (2009). For as- 
Table 3. Maxima of the restricted log-likelihood ratio test statistic (RLRT) for each trait considered in linkage disequilibrium (LD) and linkage (LK) analyses, including interval and position

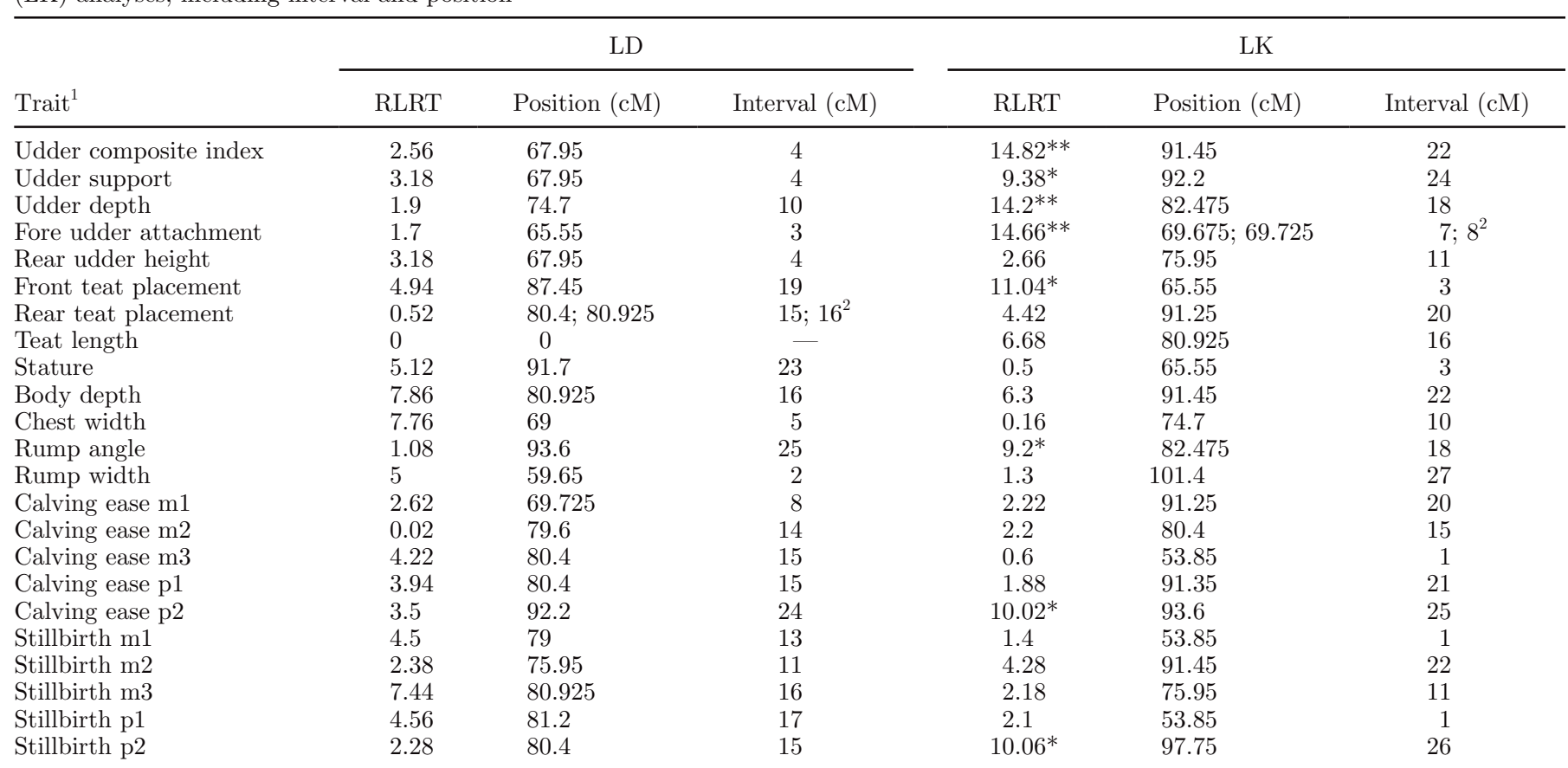

${ }^{1} \mathrm{~m} 1$ = maternal effects, first-parity calvings; $\mathrm{m} 2$ = maternal effects, second-parity calvings; $\mathrm{m} 3$ = maternal effects, third-parity calvings; 1 = direct effects, first-parity calvings; p2 = direct effects, second- and further-parity calvings.

${ }^{2}$ Restricted log-likelihood ratio test statistic showed identical results for both intervals.

${ }^{*}$ Chromosome-wide significance (RLRT $\left.=9.2\right) ;{ }^{* *}$ genome-wide significance (RLRT $=13.8$ ).

signment of confidence intervals we used the logarithm of odds drop-off method. A summary of traits included in separate LK and LD analyses is given in Table 3, and a summary of traits analyzed with an LKLD model is given in Table 4.

\section{Association Analyses}

To identify markers in tight LD with loci affecting calving and conformation traits and to exclude any specific sire effects that could occur in a paternal halfsib design, association analyses including maternally inherited marker alleles were performed. The mixed model applied to the data set included a fixed effect of the maternally inherited allele and a random polygenic effect for each marker $\times$ trait combination:

$$
y_{i j}=\mu+M_{i}+a_{j}+e_{i j}
$$

where $y$ is a vector of phenotypic observations (DYD) for sires; $\mu$ is the overall mean; $M_{i}$ is the fixed effect of the maternally inherited allele $i ; a_{j}$ is the random polygenic effect of animal $j$; and $e_{i j}$ is the random residual. The polygenic effect that also accounts for the family structure of the population was estimated using an extended pedigree of nongenotyped ancestors of geno- typed animals (7,627 animals). To account for multiple testing, a $5 \%$ experiment-wise significance threshold was obtained by Bonferroni correction of the nominal $P$-value assuming a 5\% type 1 error $\left(P_{\exp }=0.003\right)$ and 20 independent tests (5 markers flanking QTL intervals tested for 4 traits each; Table 5). For the most significantly associated marker, DIK4234, we compared solutions for allele effects for stillbirth $\mathrm{m} 3$, calving ease $\mathrm{p} 2$, stillbirth $\mathrm{p} 2$, and body depth to analyze effects of maternally inherited alleles on calving traits and body depth.

\section{RESULTS}

\section{Markers and Map}

The genetic linkage map was calculated based on a refined marker order. The marker order was previously evaluated by Baes et al. (2009) and is in accordance with published linkage maps, radiation hybrid maps, and the bovine genome assembly Btau4.0 (The Bovine Genome Sequencing and Analysis Consortium et al., 2009). In comparison to Baes et al. (2009), 2 additional SNP were incorporated in the map based on sequence information: one additional SNP within the hepcidin antimicrobial peptide $(H A M P)$ gene and one additional 
Table 4. Maxima of the restricted log-likelihood ratio test statistic (RLRT) for each trait considered in combined linkage and linkage disequilibrium analyses (LKLD), including number of genotyped sons with phenotypes, interval, and position ${ }^{1}$

\begin{tabular}{|c|c|c|c|c|c|}
\hline Trait $^{2}$ & No. of sons & RLRT & Position (cM) & Interval (cM) & Confidence interval range \\
\hline Udder support & 1,039 & 8.58 & 91.7 & 23 & \\
\hline Front teat placement & 1,039 & $10.38^{*}$ & 91.25 & 20 & $19-26$ \\
\hline Body depth & 1,039 & $10.66^{*}$ & 80.925 & 16 & $14-18$ \\
\hline Chest width & 1,036 & 2.76 & 69 & 5 & \\
\hline Stillbirth m3 & 909 & 6.58 & 80.4 & 15 & \\
\hline Stillbirth p2 & 924 & $11.86^{*}$ & 93.6 & 25 & $14-27$ \\
\hline
\end{tabular}

${ }^{1}$ For traits exceeding the chromosome-wide significance threshold, the marker intervals within an approximate $96 \%$ confidence interval are listed.

${ }^{2} \mathrm{~m} 3=$ maternal effects, third-parity calvings; $\mathrm{p} 2=$ direct effects, second- and further-parity calvings.

SNP within the calmodulin 3 (phosphorylase kinase, delta; $\boldsymbol{C A L M}$ ) gene. Sizes of marker intervals ranged from $0.05 \mathrm{cM}$ to $7.9 \mathrm{cM}$, with an average marker spacing of $1.85 \mathrm{cM}$. The number of alleles for each marker ranged from 2 for the SNP to 34 for the erythrocyte antigen marker EAC. The average polymorphism information content of the markers was 0.506. Number of alleles, polymorphism information content, position of each marker, and the positions tested for QTL are given in Table 2.

\section{Linkage and Linkage Disequilibrium Analyses}

The LK and LD analyses were conducted to initially identify QTL for conformation and calving traits in the middle to telomeric region of BTA18. A total of 3 genome-wide and 5 chromosome-wide significant QTL were identified in LK analyses (Table 3). In LD analyses, however, none of the traits identified in LK analyses achieved chromosome-wide significance. The highest RLRT in LD analyses were obtained for chest width, body depth, and stillbirth m3 (RLRT >7). A summary of the RLRT maximum and the positions and the intervals of the maxima in the LK and LD analysis for each trait are shown in Table 3.

\section{Combined Linkage and Linkage Disequilibrium Analyses}

A combined LKLD analysis was performed for each trait that reached at least a chromosome-wide significance threshold in LK analyses. Additionally, chest width, body depth, and stillbirth $\mathrm{m} 3$, for which the RLRT statistic was close to chromosome-wide significance in LD analyses (RLRT $>7$ ), were also included in LKLD analyses despite not reaching significance in the LK analysis. Genome-wide significant QTL could be identified for udder depth, fore udder attachment, udder composite index, and calving ease p2 (Table 4). Putative chromosome-wide significant QTL were detected for body depth, rump angle, front teat placement, and stillbirth p2. Concurrence of QTL affecting fore udder attachment, front teat placement, and udder composite index was observed (Figure 1a). Maxima of the test statistic for udder composite index and fore udder attachment were located in interval $21(91.35 \mathrm{cM})$ and for front teat placement were located in interval 20 $(91.25 \mathrm{cM})$. The size of confidence intervals for these udder type traits ranged from $17.1 \mathrm{cM}$ for front teat placement to $0.7 \mathrm{cM}$ for udder composite index. Analogous to the udder type traits, a similar shape of RLRT profiles was observed between body depth, stillbirth $\mathrm{m} 3$, and stillbirth p2 (Figure 1b). All 3 traits showed 2 peaks, the first peak within intervals $15(80.4 \mathrm{cM})$ to $17(81.2 \mathrm{cM})$ and the second peak within intervals 22 $(91.45 \mathrm{cM})$ to $25(93.6 \mathrm{cM})$. The maxima of the RLRT statistics for all traits included in LKLD analyses are summarized in Table 4.

\section{Association Analyses for Calving Traits and Body Type Traits}

For stillbirth m3, stillbirth p2, and body depth, the RLRT profile of the LKLD test statistic showed 2 peaks. In LD analyses, the maxima of the RLRT statistics were located in interval 15 for stillbirth $\mathrm{p} 2$ and in interval 16 for stillbirth $\mathrm{m} 3$ and body depth. Based on this information, we investigated the flanking markers of intervals 15 and 16 (DIK3014, DIK4234, and CALM3_c. $3+1678 C>T$ ) to evaluate whether one of the markers was in LD with one of the body type or calving traits. Association analyses revealed that the microsatellite marker DIK4234 showed a significant association with stillbirth $\mathrm{m} 3$, calving ease $\mathrm{p} 2$, and body 
Table 5. Association of calving and conformation traits with maternally inherited marker alleles flanking intervals $15-16$ and 20-21, based on a model including a fixed effect for maternally inherited marker alleles and a random polygenic effect

\begin{tabular}{lllc}
\hline Trait $^{1}$ & Marker $^{2}$ & Interval & Nominal $P$-value \\
\hline Stillbirth m3 & DIK3014 & $14-15$ & 0.963 \\
Calving ease p2 & DIK3014 & $14-15$ & 0.059 \\
Stillbirth p2 & DIK3014 & $14-15$ & 0.012 \\
Body depth & DIK3014 & $14-15$ & 0.929 \\
Stillbirth m3 & DIK4234 & $15-16$ & 0.001 \\
Calving ease p2 & DIK4234 & $15-16$ & 0.037 \\
Stillbirth p2 & DIK4234 & $15-16$ & 0.117 \\
Body depth & DIK4234 & $15-16$ & 0.036 \\
Stillbirth m3 & CALM3_c.3+1678C>T $>$ T & $16-17$ & 0.088 \\
Calving ease p2 & CALM3_c.3+1678C>T $>$ T & $16-17$ & 0.792 \\
Stillbirth p2 & CALM3_c.3+1678C > T & $16-17$ & 0.926 \\
Body depth & CALM3_c.3+1678C>T $>$ T & $16-17$ & 0.655 \\
Udder composite index & EAC & $19-20$ & 0.758 \\
Fore udder attachment & EAC & $19-20$ & 0.951 \\
Front teat placement & EAC & $19-20$ & 0.082 \\
Udder depth & EAC & $19-20$ & 0.729 \\
Udder composite index & DIK4596 & $21-22$ & 0.334 \\
Fore udder attachment & DIK4596 & $21-22$ & 0.761 \\
Front teat placement & DIK4596 & $21-22$ & 0.133 \\
Udder depth & DIK4596 & $21-22$ & 0.791 \\
\hline
\end{tabular}

${ }^{1} \mathrm{~m} 3$ = maternal effects, third-parity calvings; p2 = direct effects, second- and further-parity calvings.

${ }^{2}$ CALM3 $=$ calmodulin 3 (phosphorylase kinase, delta).

depth, whereas microsatellite marker DIK3014 was significantly associated with stillbirth $\mathrm{p} 2$ and calving ease p2 (Table 5). The association between DIK4234 and stillbirth $\mathrm{m} 3$ was significant at the $5 \%$ experiment-wise significance threshold, whereas association of DIK4234 with calving ease $\mathrm{p} 2$ and body depth as well as association of DIK3014 with stillbirth p2 and calving ease p2 were significant at the nominal significance level of $5 \%$. The SNP CALM3_c.3+1678C > T showed no association with any of the traits.

Further investigation of effects for maternally inherited DIK4234 alleles (Table 6) on stillbirth m3, calving ease $\mathrm{p} 2$, body depth, and stillbirth $\mathrm{p} 2$ showed that the allelic effects for all 4 traits had essentially the same direction. For all 4 traits, the most negative effect was associated with maternally inherited DIK4234 allele 189. In contrast, the most positive effect regarding stillbirth $\mathrm{m} 3$ and body depth was obtained for allele 200, and the most positive effect regarding calving ease p2 and stillbirth was obtained for maternally inherited DIK4234 allele 206. Thus, the favorable allele for the direct effect on calving ease (DIK4234 allele 189) also had a favorable effect on the maternal effect on stillbirth. Analogously, DIK4234 allele 200 showed a concordant unfavorable, positive direction of its associated maternal and direct effects.

\section{Association Analyses for Udder Type Traits}

In LKLD analyses, the maxima of the RLRT statistics for udder composite index, fore udder attachment, and front teat placement were located in intervals 20 and 21 . To evaluate whether one of the markers flanking interval 20 or 21 was associated with effects on udder composite index, fore udder attachment, front teat placement, or udder depth, an association analysis including maternally inherited alleles of flanking markers EAC (interval 19-20) and DIK4596 (interval 21-22) was performed. Association analyses indicated that DIK4569 and EAC were not in linkage disequilibrium with causal loci affecting udder type traits (Table 5). Only front teat placement showed a tendency to be associated with markers EAC and DIK4569, but did not attain statistical significance $(P=0.088$ and 0.133 , respectively).

\section{DISCUSSION}

\section{Body Type and Calving Traits}

Applying LKLD methods revealed a genome-wide significant QTL for calving ease p2 and chromosome-wide significant QTL for body depth, rump angle, and stillbirth p2 on BTA18 in the German Holstein population. We did not find indication of QTL affecting stature, chest width, or rump width. The maxima of the RLRT statistic in LKLD analyses were found in intervals 16 and 15 for body depth and stillbirth $\mathrm{m} 3$, in interval 24 for rump angle and calving ease p2, and in interval 25 for stillbirth p2. Within this region, Thomasen et al. (2008) reported QTL for direct effects on stillbirth, calf size, and calving difficulties when analyzing calving 
Table 6. Solutions for maternally inherited DIK4234 allele effects for stillbirth m3, calving ease p2, stillbirth p2, and body depth ${ }^{1}$

\begin{tabular}{|c|c|c|c|c|c|c|c|c|}
\hline \multirow[b]{2}{*}{ Maternal allele } & \multicolumn{2}{|c|}{$\begin{array}{l}\text { Stillbirth m3 } \\
(P=0.001)\end{array}$} & \multicolumn{2}{|c|}{$\begin{array}{l}\text { Calving ease p2 } \\
\quad(P=0.037)\end{array}$} & \multicolumn{2}{|c|}{$\begin{array}{l}\text { Stillbirth p2 } \\
(P=0.117)\end{array}$} & \multicolumn{2}{|c|}{$\begin{array}{l}\text { Body depth } \\
(P=0.036)\end{array}$} \\
\hline & $\begin{array}{l}\text { Number } \\
\text { of alleles }\end{array}$ & Solutions & $\begin{array}{l}\text { Number } \\
\text { of alleles }\end{array}$ & Solutions & $\begin{array}{l}\text { Number } \\
\text { of alleles }\end{array}$ & Solutions & $\begin{array}{l}\text { Number } \\
\text { of alleles }\end{array}$ & Solutions \\
\hline 188 & 215 & 0 & 219 & 0 & 219 & 0 & 237 & 0 \\
\hline 189 & 87 & -0.0023 & 89 & -0.0022 & 89 & -0.0012 & 93 & -68.988 \\
\hline 200 & 219 & 0.0046 & 219 & 0.0035 & 219 & 0.0006 & 240 & 51.378 \\
\hline
\end{tabular}

${ }^{1} \mathrm{~m} 3=$ maternal effects, third-parity calvings; $\mathrm{p} 2$ = direct effects, second- and further-parity calvings.

traits for first parity in Danish Holsteins. In our analyses, the QTL for calving ease p2 and stillbirth p2 were detected within the same marker interval as reported in Thomasen et al. (2008). This coincidence indicated that the QTL affecting direct effects on calving performance might have effects on first- and further-parity calvings. We did not detect a QTL for stillbirth first parity and calving ease first parity in our analyses; this may be related to the low number of first-parity records in the data set because of the progeny testing scheme in Germany. Another QTL for maternal stillbirth reported by Thomasen et al. (2008) was located in marker interval BMON117-BM2785. Within this marker interval, we identified microsatellite marker DIK4234 to be associated with stillbirth m3, implying that the QTL affecting maternal effects on calving performance reported by Thomasen et al. (2008) could also have effects on later-parity calvings.

Cole et al. (2009) reported a single SNP (ss86324977) to be associated with body depth, rump width, stature, strength, daughter calving ease, and sire calving ease in North American Holstein bulls. Kolbehdari et al. (2008) reported on 2 SNP either associated with overall conformation, overall rump, and mammary system (rs41636734) or having direct effect on calving ease (rs41636749) in Canadian Holsteins. The SNP highlighted by Cole et al. (2009) and Kolbehdari et al. (2008) were located approximately in the middle between marker interval 15 and marker interval 25 in our analyses. Markers DIK4234 and DIK3014 are flanking markers of interval 15, and our results indicated that they are associated with stillbirth $\mathrm{m} 3$, calving ease $\mathrm{p} 2$, body depth, and stillbirth p2. On the other hand, the maxima of the RLRT test statistics for stillbirth p2 and calving ease p2 in LKLD analyses were located in intervals 24 and 25, respectively. In our analyses, the divergent location of maxima in QTL test statistics for stillbirth p2 and calving ease p2 and the position of significantly associated markers for these traits could be a result of the different methods (LKLD, association analysis) applied and the size of marker intervals in this region. In LKLD analyses, LK and LD information including haplotype identical by descent probabilities are merged, whereas, in association analyses, only LD between alleles at the marker and the putative causal mutation affecting the target trait is tested. Taken together, the position of the SNP reported by Cole et al. (2009), the results from Kolbehdari et al. (2008), and our analyses indicate that there might be a single locus affecting body conformation traits and calving traits in the telomeric region on BTA18.

Comparison of solutions for maternally inherited DIK4234 allele effects showed that this marker is associated with effects on stillbirth m3, body depth, calving ease p2, and, less significantly, stillbirth p2. The DIK4234 effects on these traits are favorably correlated. This result confirms observations from Cole et al. (2009) obtained from association analyses of multiparity EBV. The authors also reported a favorable correlation of maternal and direct effects on calving traits for SNP ss86324977. Thus, our results support the hypothesis of a locus with favorably correlated effects on maternal traits and direct effects on calving traits. Additionally, the concurrent association of maternally inherited marker alleles with body depth and maternal effect on calving ease for marker DIK4234 indicates that variation in body conformation might be the cause for divergent performance regarding calf delivery associated with this marker. This suggests a respective functional background of the QTL for calving traits in the German Holstein population. However, the question whether this is because of direct effects resulting in a disproportion in size of calf and dam as suggested by Cole et al. (2009) and Thomasen et al. (2008) or whether this is because of indirect effects from yet-unrecognized physiological effects of the locus remains open.

\section{Udder Type Traits}

Initial QTL analyses applying LK methods identified genome-wide significant QTL for udder composite 

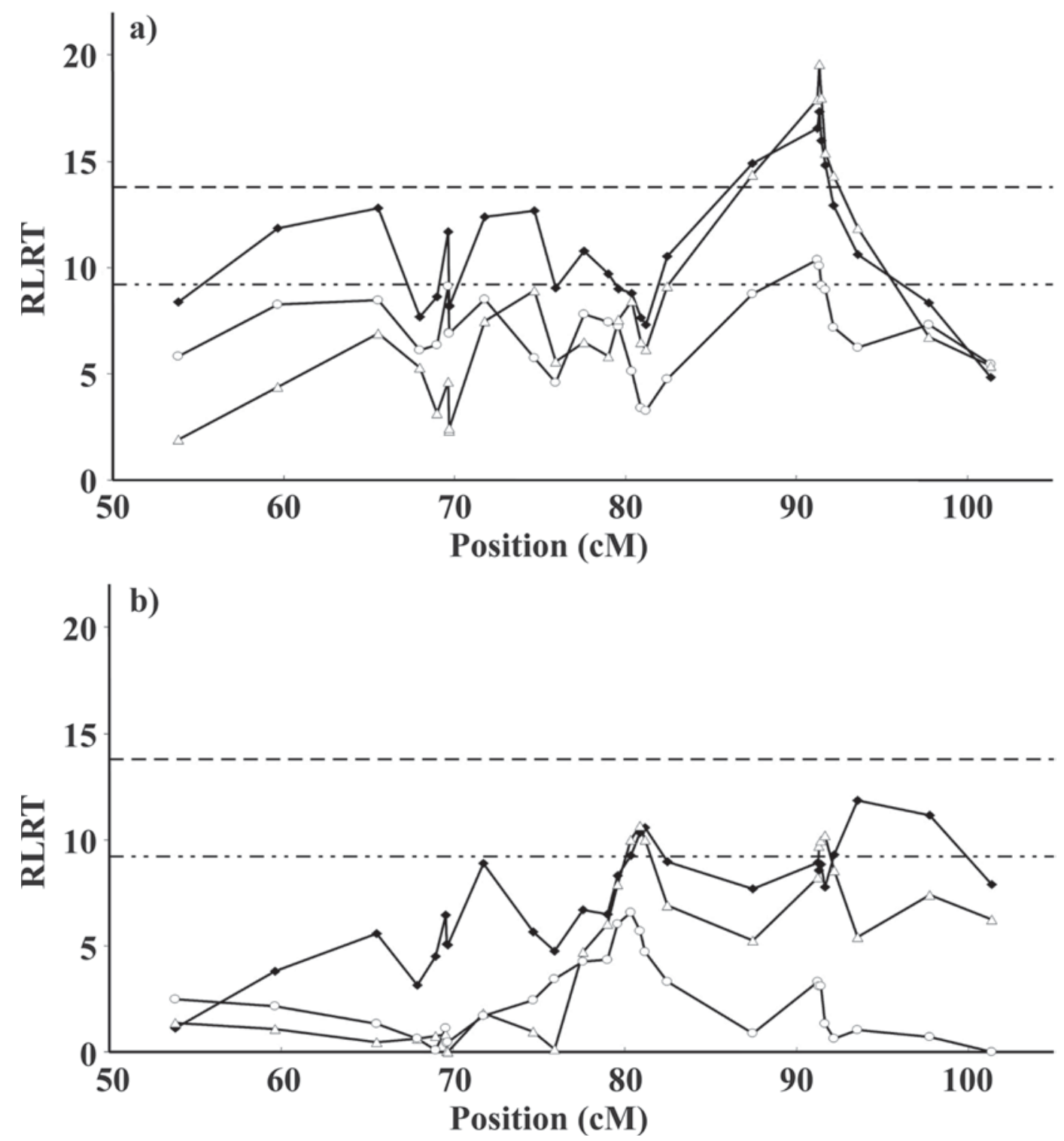

Figure 1. Restricted log-likelihood ratio (RLRT) profile for a combined linkage and linkage disequilibrium analysis for overlapping QTL effecting a) fore udder attachment $(\bullet)$, front teat placement $(O)$, and udder composite index $(\Delta)$, and b) maternal effect on stillbirth for thirdparity calvings $(\bigcirc)$, body depth $(\Delta)$, and direct effects on stillbirth for further parity calvings $(\bullet)$ on Bos taurus autosome 18 . The upper dashed line indicates the genome-wide significance threshold, and the lower dashed line indicates the chromosome-wide significance threshold.

index, udder depth, and fore udder attachment as well as chromosome-wide significant QTL for udder support and front teat placement, whereas, in LD analyses, none of the udder type traits achieved chromosomewide significance. The LKLD analyses confirmed the QTL for udder composite index, udder depth, fore udder attachment, and front teat placement and showed concurrent maxima of the RLRT statistics within a region comprising $10 \mathrm{cM}$ in the telomeric area on BTA18. Within this region, Kolbehdari et al. (2008) reported SNP rs41636734 to be associated with mammary system and overall conformation in Canadian Holsteins, and Ashwell et al. (2005) reported QTL for rear udder height and udder depth in United States Holsteins. For rear udder height, rear teat placement, udder support, or teat length, which are also included in the udder composite index, no QTL were detected in the families we analyzed. Therefore, we assume to have identified a QTL for udder composite index that predominantly affects fore udder attachment, udder depth, and front teat placement.

Several studies have reported QTL for SCS on BTA18 in German Holstein cattle. Brink (2003), Kühn et al. (2003), and Xu et al. (2006) reported a QTL for SCS 
at marker TGLA227 in the telomeric region on BTA18, whereas Baes et al. (2009) reported a QTL for SCS in the middle to telomeric region on BTA18. In addition to the QTL at marker TGLA227, Xu et al. (2006) suggested a second QTL for SCS at marker BM2078 in German Holsteins, whereas Ashwell et al. (1997) reported a QTL for SCS in United States Holstein. Our analyses indicated QTL for udder composite index, fore udder attachment, and front teat placement in marker intervals 20-21. Marker BM2078 was a flanking marker of intervals 20 and 21 in our analyses, indicating that the second QTL indicated by Xu et al. (2006) might be attributed to udder type traits affecting SCS. The wellestablished favorable effects of a tightly attached udder on udder health (Rupp and Boichard, 2003) suggest that one of the QTL for SCS maybe affected by udder type traits.

Further investigation is required to identify markers in LD with the causal mutation(s) on a populationwide level and to locate the causal mutation(s). For this purpose, the number of families included in the analyses should be increased to minimize the effect of single-grandsire families that are homozygous for one of the QTL. Based on the information that there could be more than one QTL for SCS on BTA18 in the German Holstein population, and that QTL affecting udder type traits and SCS are segregating in the same region, further analyses should include multiple trait and multiple QTL models to evaluate potential effects of QTL for udder type traits on genetic variation of SCS.

\section{CONCLUSIONS}

Combining results from LK, LD, and LKLD and from association studies with maternally inherited marker alleles, we were able to confirm previously reported QTL for calving traits in German Holstein cattle. Furthermore, we identified new QTL for body type and udder type traits that might be correlated with effects of QTL for calving and udder health traits located on BTA18. Our results suggest that the telomeric region on BTA18 has an influence on conformation traits and calving performance, and loci affecting conformation, calving, and udder health on BTA18 may also contribute to the genetic variance of functional herd life in the German Holstein population. Further analyses are required to identify the causal mutations affecting conformation and calving traits on BTA18 and to investigate the correlation of effects for loci associated with effects on body type traits and calving traits as well as the correlation of effects for loci associated with effects on udder type traits and udder health. A more detailed picture of the mechanisms affecting calving traits and udder health traits on BTA18 may be useful to verify whether conformation traits affect calving traits by directly targeting calf size, conformation of the dam, or other indirect pathways. Furthermore, it will be helpful to decide which markers would be useful to markerassisted selection in dairy cattle breeding programs.

\section{ACKNOWLEDGMENTS}

The authors thank F. Reinhardt (VIT, Verden, Germany) and the Vereinigte Informationssysteme Verden w.V. (VIT) for assistance with the selection of animals and for providing data. Financial support of the German Federal Ministry of Education and Research (BMBF; Berlin, Germany; projekt FUGATO M.A.S.net, FKZ 0313390A) and the Development Association for Biotechnology Research (FBF), e.V. (Bonn, Germany) is gratefully acknowledged.

\section{REFERENCES}

Ashwell, M., C. E. J. Rexroad, R. Miller, P. Vanraden, and Y. Da. 1997. Detection of loci affecting milk production and health traits in an elite US Holstein population using microsatellite markers. Anim. Genet. 28:216-222.

Ashwell, M. S., D. W. Heyen, J. I. Weller, M. Ron, T. S. Sonstegard, C. P. Van Tassell, and H. A. Lewin. 2005. Detection of quantitative trait loci influencing conformation traits and calving ease in Holstein-Friesian cattle. J. Dairy Sci. 88:4111-4119.

Baes, C., B. Brand, M. Mayer, C. Kuhn, Z. Liu, F. Reinhardt, and N. Reinsch. 2009. Refined positioning of a quantitative trait locus affecting somatic cell score on chromosome 18 in the German Holstein using linkage disequilibrium. J. Dairy Sci. 92:40464054.

Brink, M. 2003. Ein Beitrag zur Feinkartierung von QTL-Regionen für Eutergesundheit beim Rind. Schriftenreihe des Instituts für Tierzucht und Tierhaltung der Christian-Albrechts-Universität zu Kiel 142, Kiel, Germany.

Cole, J. B., P. M. VanRaden, J. R. O'Connell, C. P. Van Tassell, T. S. Sonstegard, R. D. Schnabel, J. F. Taylor, and G. R. Wiggans. 2009. Distribution and location of genetic effects for dairy traits. J. Dairy Sci. 92:2931-2946.

Essl, A. 1998. Longevity in dairy cattle breeding: A review. Livest. Prod. Sci. 57:79-89.

Green, P., K. Falls, and S. Crooks. 1990. Documentation of CRI-MAP. Version 2.4. Washington University School of Medicine, St. Louis, MO.

Groen, A. F., T. Steine, J. J. Colleau, J. Pedersen, J. Pribyl, and N. Reinsch. 1997. Economic values in dairy cattle breeding, with special reference to functional traits. Report of an EAAP working group. Livest. Prod. Sci. 49:1-21.

Holtsmark, M., B. Heringstad, P. Madsen, and J. Odegard. 2008 Genetic relationship between culling, milk production, fertility, and health traits in Norwegian Red cows. J. Dairy Sci. 91:40064012.

Kalm, E. 2002. Development of cattle breeding strategies in Europe. Arch. Tierz. 45:5-12.

Kolbehdari, D., Z. Wang, J. R. Grant, B. Murdoch, A. Prasad, Z. Xiu, E. Marques, P. Stothard, and S. S. Moore. 2008. A whole-genome scan to map quantitative trait loci for conformation and functional traits in Canadian Holstein bulls. J. Dairy Sci. 91:2844-2856.

Kühn, Ch., J. Bennewitz, N. Reinsch, N. Xu, H. Thomsen, C. Looft, G. A. Brockmann, M. Schwerin, C. Weimann, S. Hiendleder, G. Erhardt, I. Medjugorac, M. Forster, B. Brenig, F. Reinhardt, R. Reents, I. Russ, G. Averdunk, J. Blumel, and E. Kalm. 2003. Quantitative trait loci mapping of functional traits in the German Holstein cattle population. J. Dairy Sci. 86:360-368. 
Liu, K., and S. V. Muse. 2005. PowerMarker: An integrated analysis environment for genetic marker analysis. Bioinformatics 21:2128 2129 .

Lund, M. S., G. Sahana, L. Andersson-Eklund, N. Hastings, A. Fernandez, N. Schulman, B. Thomsen, S. Viitala, J. L. Williams, A. Sabry, H. Viinalass, and J. Vilkki. 2007. Joint analysis of quantitative trait loci for clinical mastitis and somatic cell score on five chromosomes in three Nordic dairy cattle breeds. J. Dairy Sci. 90:5282-5290.

Mark, T. 2004. Applied genetic evaluations for production and functional traits in dairy cattle. J. Dairy Sci. 87:2641-2652.

Mark, T., W. F. Fikse, P. G. Sullivan, and P. M. VanRaden. 2007. Prediction of genetic correlations and international breeding values for missing traits. J. Dairy Sci. 90:4805-4813.

Oltenacu, P. A., and B. Algers. 2005. Selection for increased production and the welfare of dairy cows: Are new breeding goals needed? Ambio 34:311-315.

Rupp, R., and D. Boichard. 2003. Genetics of resistance to mastitis in dairy cattle. Vet. Res. 34:671-688.

Schmid, D. O., and H. G. Buschmann. 1985. Blutgruppen bei Tieren. Enke Verlag, Stuttgart, Germany.

Schnabel, R. D., T. S. Sonstegard, J. F. Taylor, and M. S. Ashwell. 2005. Whole-genome scan to detect QTL for milk production, conformation, fertility and functional traits in two US Holstein families. Anim. Genet. 36:408-416.

Seidenspinner, T., J. Bennewitz, F. Reinhardt, and G. Thaller. 2009. Need for sharp phenotypes in QTL detection for calving traits in dairy cattle. J. Anim. Breed. Genet. doi:10.1111/j.14390388.2009.00804.x.
Simianer, H., H. Solbu, and L. R. Schaeffer. 1991. Estimated genetic correlations between disease and yield traits in dairy cattle. J. Dairy Sci. 74:4358-4365.

Thaller, G., W. Kramer, A. Winter, B. Kaupe, G. Erhardt, and R. Fries. 2003. Effects of DGAT1 variants on milk production traits in German cattle breeds. J. Anim. Sci. 81:1911-1918.

The Bovine Genome Sequencing and Analysis Consortium 2009. The genome sequence of Taurine cattle: A window to ruminant biology and evolution. Science 324:522-528.

Thomasen, J. R., B. Guldbrandtsen, P. Sorensen, B. Thomsen, and M. S. Lund. 2008. Quantitative trait loci affecting calving traits in Danish Holstein cattle. J. Dairy Sci. 91:2098-2105.

Thomsen, H., N. Reinsch, N. Xu, C. Looft, S. Grupe, C. Kuhn, G. A. Brockmann, M. Schwerin, B. Leyhe-Horn, S. Hiendleder, G. Erhardt, I. Medjugorac, I. Russ, A. Forster, B. Brenig, F. Reinhardt, R. Reents, J. Blumel, G. Averdunk, and E. Kalm. 2002. Mapping of the bovine blood group systems J, N', R', and Z show evidence for oligo-genetic inheritance. Anim. Genet. 33:107-117.

Thomsen, H., N. Reinsch, N. Xu, C. Looft, S. Grupe, C. Kuhn, G. A. Brockmann, M. Schwerin, B. Leyhe-Horn, S. Hiendleder, G. Erhardt, I. Medjugorac, I. Russ, M. Forster, B. Brenig, F. Reinhardt, R. Reents, J. Blumel, G. Averdunk, and E. Kalm. 2000. A male bovine linkage map for the ADR granddaughter design. J. Anim. Breed. Genet. 117:289-306.

Xu, N., S. Paul, J. Bennewitz, N. Reinsch, G. Thaller, F. Reinhardt, C. Kühn, M. Schwerin, G. Erhardt, C. Weimann, H. Thomsen, S Mishra, and E. Kalm. 2006. Confirmation of quantitative trait loci for somatic cell score on bovine chromosome 18 in the German Holstein. Arch. Tierz. 49:111-119. 